\title{
INFLUENCE OF NATIONAL CULTURE AND ENVIRONMENTAL AWARENESS ON THE DEMAND OF DOMESTIC CAMPING TOURISM - A CROSS-COUNTRY ANALYSIS AMONG EUROPEAN COUNTRIES
}

\author{
Zsuzsanna Bacsi*, Angéla Szanati* \\ * Szent István University, Georgikon Campus, Department of Economics, Social Sciences \\ and Rural Development, 16 Deák F. Str, H-8360 Keszthely, Hungary, \\ bacsi.zsuzsanna@szie.hu, angieszan.@gmail.com
}

\begin{abstract}
Influence of national culture and environmental awareness on the demand for domestic camping tourism - a cross-country analysis among European countries

Natural resources are major resources for tourism. Nature-based tourism is one of the tourism forms with an increasing appeal. Camping tourism is an important part of nature-based tourism and it plays a significant role in domestic tourism, representing approximately $10 \%$ of total tourist nights in the EU, though countries differ to a great extent. The decision to choose a camping holiday depends on the tourists' preferences and values. The aim of the paper is to identify the extent to which national cultural traits and environmental consciousness influence the domestic demand for camping holidays. The paper demonstrates by way of multiple regression analysis of $25 \mathrm{EU}$ countries in 7 years $(2012-2018)$ that this decision is correlated to Hofstede's 6 national cultural dimensions and national income levels, while the environmental awareness of the population does not have any significant influence on it.
\end{abstract}

Key words: nature-based tourism, camping, environmental issues, Hofstede- cultural dimensions, European Union

\section{INTRODUCTION}

Tourism, as an industry relies heavily on the natural landscape as a resource. Natural beauty or nature-based services are among its main appeals. Therefore environmentally conscious behaviour both by tourist service providers, and by the tourists themselves, is crucial for the future sustainability of the tourism industry. Since the 1990s, sustainable development has emerged as a core issue in tourism operations, requiring responsibility to extend beyond economic issues, leading to the acceptance of the concepts of responsible and ethical consumption. The issues of responsibility and sustainability have gained ground in tourism geographies and tourism studies. Consumers showing increasing environmental awareness guide the industry towards more sustainable operations (Saarinen 2014).

Tourists staying in campsites and caravan parks usually feel more attached to nature, and are more concerned about its protection (Sandell and Öhman 2010). Campsites are usually associated with a lower environmental impact per tourist per night than other types of accommodations. Indoor heated and cooled areas per number of guests are much smaller than in hostels, guest houses and hotels. Campgrounds are not directly involved in laundering bedclothes and towels, and if campers use on-site laundry machines these are small-scale ones (EC 2013). However, camping tourism is basically a form of holiday-making, therefore its choice represents a consumption activity of natural resources, including landscapes. The choice of favoured tourist destinations as geographic places, is based on the cultur- 
al and environmental features of the chosen geographic place, and is influenced not only by the physical traits of an area, but by culture, social aspects and the way of thinking of tourists and the host community (Minca 2013). The 'consumers' of camping services are perceived as the active recipients of the transmitted marketing messages. The content of the information, if consciously or unconsciously transmitted, or the messages on the significance of the destination/camping brand are projected by the set of cultural codes and then transformed into the image of the final destination/camping brand image (Matlovičová et al. 2019).

The aim of the present research is to identify the extent to which national cultural traits and environmental consciousness influenced the domestic demand for camping holidays in the European Union, in the time period $2012-2018$. The national cultural traits are quantified by Hofstede's six cultural dimensions (Hofstede et al. 2010). The citizens' attitude towards the environment is also included in the analysis. This environment-related attitude is measured by the proportion of people who consider environmental issues among the major challenges for their countries. Other control factors are national income level and time. Though camping tourism has been extensively analysed, and the relationship of national cultural traits to tourist behaviour is also well researched, a cross-country analysis about the behaviour of domestic campsite tourists in relation to their national culture and environmental awareness has not been done before. This aspect of tourism can, however, show the inclination of the population towards nature-based activities, and the possibilities for tourism, a main economic activity, to develop in more sustainable directions.

\section{PROBLEM FORMULATION AND LITERATURE REVIEW}

In recent years, camping tourism is recognized as a growing segment of the broader tourism industry, evolving from an inexpensive stay in a rural environment into a highly fragmented niche tourism sector (Brooker and Joppe 2014 and Brochado and Pereira 2017). The main motives for the choice of this form of vacation include leisure combined with educational ideals, the cult of the outdoor life, often in a coastal or countryside setting (Ward and Hardy 1986).

Camping is a recreational activity in the outdoors, where the typical accommodation facility is tents, caravans, campervans, motor-homes or similar specially designed or adapted vehicles for shelter (Ryalls and Petri 2013). Camping was at one time only a rough, back-to-nature, inexpensive holiday option for nature lovers, but it later became the standard holiday for vast numbers of ordinary families, associated with flexible and mobile accommodation facilities and inseparable relationship with the natural environment (Blichfeldt and Mikkelsen 2014 and Mikulic et al. 2017). Outdoor hospitality has been a popular activity amongst North Americans, Europeans, Australians and New Zealanders, and is gaining popularity in Asia, too (Brooker and Joppe 2013).

Research about camping tourism has mainly focused on campsite choice, and on tourist satisfaction with campsite experience. A study from campsite facilities in the coastal part of Croatia (Mikulic et al. 2017) revealed that safety and ecological standards are among the most important attributes for both campsite choice and for the camper's experience. A survey conducted in a camping area in Apulia, South Italy showed that local culture, and refreshment were positively related to tourist satisfaction in the camping area (Peluso et al. 2019). Nature, as the main appeal, is 
equally important for more demanding tourists. Research in Portugal revealed that from the guests' perspective the main components of tourist satisfaction include five facets: tangibles, staff, nature-based experiences, food and activities (Brochado and Pereira 2017). Glamping - a combination of the words 'glamour' and 'camping' - is an emerging concept in camping that combines comfort and direct contact with nature, and being a form of nature-based holiday, increasingly incorporates convenient, or even luxurious elements in its facilities, linking indoor and outdoor hospitality offers (Brooker and Joppe 2013 and Brochado and Pereira 2017). This form of tourism is very popular in Australia and New Zealand, as well as in the European Union. Camping is an essential element of rural and wilderness recreation. However, a study conducted in 81 wilderness campsites in the USA revealed that campers in the wilderness may have a considerable negative longterm impact on the environmental conditions in the campsite area (Ward and Hardy 1986 and Eagleston and Marion 2017). Empirical results seem to agree that the beauty of nature, the vicinity of a river or a lake, the interaction with wildlife, tranquillity and relaxation in the natural environment, activities in natural surroundings (swimming, hiking, rowing and forest walks) are important components of visitor satisfaction (Brochado and Pereira 2017). In the seven years between 2012 and 2018 approximately $10 \%$ of the tourist nights spent by EU citizens in rented accommodation were spent in campsites, caravan or trailer parks, with a considerably higher proportion for domestic tourism (14\%) than for outbound tourism (7\%). Table 1 summarises the main research topics related to camping tourism and its different aspects.

\section{Tab. 1. Research topics related to camping tourism and national culture}

\begin{tabular}{cc}
\hline Main research topic & References \\
\hline $\begin{array}{c}\text { General motivation for camping } \\
\text { tourism }\end{array}$ & Brooker and Joppe 2014 and Brochado and Pereira 2017 \\
$\begin{array}{c}\text { Satisfaction with the campsite } \\
\text { experience, including glamping }\end{array}$ & $\begin{array}{c}\text { Wrooker and Joppe 2013, Brochado and Pereira 2017, } \\
\text { Mikulic et al. 2017 and Peluso et al. 2019 }\end{array}$ \\
$\begin{array}{c}\text { Impacts of camping tourism } \\
\text { on the environment }\end{array}$ & Ward and Hardy 1986 and Eagleston and Marion 2017 \\
$\begin{array}{c}\text { National cultural traits and their } \\
\text { relation to camping tourism }\end{array}$ & Gursoy and Chen 2012, Li et al. 2007 and Li 2016 \\
$\begin{array}{c}\text { Cultural traits and tourist behaviour } \\
\text { Pizam and Telisman-Kosute 1989, Pizamm and Sussmann }\end{array}$ \\
1995, Litvin et al. 2004, Reisinger and Crotts 2010, Manrai \\
and Manrai 2011 and Buafai and Khunon 2016
\end{tabular}

The European Union regularly surveys its population about the most serious issues that their countries have to face in the near future. In the Eurobarometer surveys (EC 2012 - 2019) respondents were asked to choose the two most important issues from a list containing immigration, terrorism, public finances, the economic situation, climate change, unemployment, the EU's influence in the world, rising prices/inflation/cost of living, the environment, crime, pensions, energy supply, taxation. As the surveys reveal, climate and the environment have been among the main concerns of the European citizens, mentioned as most important by $5.2 \%$ of the respondents in 2013 and $19.7 \%$ in 2019 . Whether this awareness is reflected in the economic activities of people is an exciting research question. The proportion 
of respondents attributing the first or second rank in importance to climate change, the environment or energy supply issues, reflect an attitude that may influence their sensitivity towards nature in general, too. Therefore, even if concern over climate change or energy supply issues is not directly related to nature and landscape, it is still an indication of the respondents' awareness of the importance of external natural surroundings.

Environmental degradation is mainly due to the direct or indirect overconsumption of resources by the wealthy (Shaker 2015). Sustainable development indicators mostly rely on an environmental assessment approach while somewhat neglecting the economic and social aspects of sustainability, while the research by Shaker (2015) underlines the relevance of societal, governmental and management aspects of sustainability. Therefore it justifies our approach, that measures the direct consumption of natural resources, i.e. landscape, in the form of camping tourism, and its relations to the population's cultural traits, that influence their consumption patterns in general, and tourism consumption, in particular.

People's awareness of environmental problems depends on the general cultural traits, beliefs and values of the population. The inherent values and beliefs of people determine the way how they view the surrounding world. Therefore it is reasonable to assume, that basic national cultural values will have an impact on the environmental awareness and the resulting activity patterns experienced in any country (Halkos and Tzeremes 2013 and Gould et al. 2018).

National cultures are often characterised by means of distinct dimensions, of which several different sets can be found in the literature (for a detailed description see Steers et al. 2010, p. 411). The most widely used model of culture is that of Hofstede, and cultural dimension values of this model are available for most of the countries of the world. Hofstede (1980) used the data about the employees' workrelated values in the subsidiaries of IBM, and then applied factor analysis to arrive to the dimension of individualism-collectivism, power distance, masculinityfemininity, and uncertainty avoidance. Later two new dimensions, namely long vs. short term orientation, and indulgence vs. restraint were added to the model, and the data from the World Values Survey, based on the European Values Survey and European Social Survey (EVS 2010 and ESS 2008), led to a new calculation of these dimensions (Minkov 2007 and Hofstede et al. 2010). Although many other concepts have been evolved, the Hofstede dimensions have been widely used in analysing cross-country cultural differences (Kaasa et al. 2016).

The cultural dimensions and country scores were validated several times in various contexts between 1990 and 2002 (see Hofstede et al. 2010, p. 35), and the country-wise dimensions were published online (Hofstede Insights 2016). Although these dimensions are relatively independent of each other, it is a wellestablished fact, that GDP per capita correlates with power distance (negatively) and with individualism (positively), while it does not correlate with uncertainty avoidance or masculinity. Therefore, when working with these cultural dimensions, GDP has to be included in the analyses. In Europe, countries with high per capita GDP values show smaller within-country disparities of income, compared to less affluent societies. High disparities are particularly apparent in Romania, Hungary, and Bulgaria (Neszmélyi et al. 2016). Such disparities are reflected in many other aspects of countries, and suggest, that high disparities exist mainly in countries where Hofstede's cultural dimensions show high uncertainty avoidance and a low level of indulgence. 
Cultural tourism means visiting particular destinations in order to experience and learn about a particular culture. This can be done intentionally, attending events and visiting museums and historic buildings, or tasting the local food and drinks, or it can be experienced unintentionally by cultural immersion, i.e., by interaction with local people, their language, customs, cuisine, which are an inevitable part of a person's holiday. The main motivation for cultural tourism is often associated with learning about different countries and different cultures, the more culturally distant destinations being the more exciting ones for the visitor. Thus the cultural distance between the generating region and the destination often encourages tourists to participate in cultural tourism activities, although an opposite trend also exists, when tourists may be unwilling to visit culturally very distant areas (Fan et al. 2017). A typical feature of camping tourism is its individuality. This is associated with movement across the region visited, contacts with local people and a completely different perception of local and regional culture. Cultural diversity may lead to enhanced tourism competitiveness (Bacsi 2017).

The cultural difference of nations regarding tourist behaviour has been extensively researched, focusing on outbound international tourists, and their expectations and satisfaction, motivation and choice of destination, even in relation to the environment (Pizam and Telisman-Kosute 1989, Pizam and Sussmann 1995, Litvin et al. 2004, Reisinger and Crotts 2010, Manrai and Manrai 2011 and Buafai and Khunon 2016). Most of these studies established the relationship of tourist behaviour to individualism, long-term orientation, and uncertainty avoidance, while only 4 of 17 studies assessed the role of masculinity or power distance. Buafai and Khunon (2016) contrasted tourism satisfaction to the Hofstede dimensions of the tourists' home country, on a sample of 386 tourists coming from 6 countries. They established that generally masculinity was negatively correlated with overall satisfaction, and higher uncertainty avoidance implied better satisfaction with services. People of more masculine cultures require top services, therefore tend to be less satisfied, while those avoiding uncertainty tend to deal with tour agents, who take care of all their needs. Reisinger and Crotts (2010) compared 608 tourists from 8 countries by their Hofstede dimensions, and found that the cultural traits of tourists do not differ much from the general cultural profiles of their countries as established by the original Hofstede results. Murgaš (2019) analysing the satisfaction with life in the Czechia found, that it is related to the cultural characteristics of the nation state. In contrasting the Czech society to the Danish one, he states that Denmark is the happiest country in the world according to the Global Happiness Index, and Czechia is just around the average, while the Hofstede cultural dimensions of the two countries considerably differ. The Danes are more individualistic, live with more long-term orientation and less power distance, and they are a considerably more feminine society than the Czech people. The quality of life is largely influenced by the interactions of the 'inner environment' and the 'external environment'. The first one includes the personal traits of individuals, their values and beliefs, closely interrelated with the general social and cultural values of the nation state, that are components of the external environment. The other important component of the external environment is natural environment and landscape, so camping tourism, as an indicator of demand for, and consumption of landscape and nature represent an interaction between these external and internal components. Thus the quality of life is influenced by cultural diversity, the social and political environment, the natural surroundings and the individuals' perceptions of a given territory (Klamár and Gaval'ová 2018). 
This supports our idea that tourist decisions may be assessed with regard to national cultural features. However, all these results deal with international tourists and their encounters in foreign destinations. The choice of geographic scale is a problem of current tourism geography. Generally, geographical tourism data is available for countries and nations, but the nations' sizes vary to a large extent in terms of population, land area and economy (as for e.g., Monaco and China), leading to the divide between international and domestic tourism and the preoccupation with air transport. The different scales of nations cause that almost all tourist trips by citizens of small countries are 'international', and most trips by visitors coming from large countries are 'domestic'. The significance of the relations between domestic and international tourism is reflected in tendencies to overvalue the importance of the relatively easily measurable international tourism and to ignore domestic tourism that is more difficult to measure (Pearce 1995 and Peeters and Landré 2012). Although research is also abundant about domestic tourism, up to now we do not now about any studies that compared domestic tourist behaviour across countries by Hofstede dimensions. Research about the visitors of a forest recreation area in California ( $\mathrm{Li}$ et al., 2007) found relevant cultural traits that influenced domestic visitors' behaviour. Domestic tourists tended to have less than average hierarchical beliefs, more than average feminine values and more than average tendency to uncertainty avoidance. Tourists' decisions to visit natural sites were also found to be influenced by cultural values in a national park in Taiwan (Li 2016). Campers are often motivated by escape and solitude, though they still prefer to spend time in their own small social circle, but campground campers - in contrast with backcountry campers - tend to value the accessibility and facilities more than solitude (Gursoy and Chen 2012). Our paper analyses domestic tourists' behaviour in camping grounds in their home countries from a cultural viewpoint, based on Hofstede's 6 cultural dimensions.

\section{MATERIALS AND RESEARCH METHODOLOGY}

The analysis was based on secondary data of 7 years (from 2012 to 2018) and 25 member states of the EU (Cyprus, Estonia and Malta were omitted due to a lack of data). As the database contains panel data, multiple regression was done by statistical software developed for panel data analysis to account for spatial and temporal effects. The most appropriate package was the PLM package (Croissant and Millo 2008) developed in „R" (R Core Team 2013), dealing with fixed and random effects for panel data. The data sources and variables of the analysis are described in Tab. 2. The applied multiple regression model structure is the following:

$$
y=\alpha+\beta \times X+\gamma \times C+\varepsilon,
$$

where $y$ is the dependent variable (i.e. domestic camping nights as $\%$ of total domestic nights), $X$ is the set of variables describing the Hofstede cultural dimensions, $C$ is the set of control variables (year, environmental awareness, and GDP per capita), $\alpha$ is the constant value, $\beta$ and $\gamma$ are the vectors of regression coefficients for the Hofstede variables and the control variables, respectively, and $\varepsilon$ is the error term of the regression estimation. 
Tab. 2. List of variables and data sources applied in the analysis

\begin{tabular}{ccc}
\hline Variable name & Variable meaning & Data source \\
\hline CampNPct & $\begin{array}{c}\text { Domestic tourist nights in campsites as \% of total } \\
\text { domestic tourist nights }\end{array}$ & $\begin{array}{c}\text { Eurostat 2019a, Eurostat } \\
\text { 2019b }\end{array}$ \\
GDP_per_cap & $\begin{array}{c}\text { GDP per capita }(€) \text {, constant 2010 price levels } \\
\text { \% of population considering environment, climate } \\
\text { and energy issues crucial for the country }\end{array}$ & EC 2019c \\
ENAW & Hofstede cultural index values, as of 2015 & Hofstede Insights 2016 \\
\hline PDI & $\begin{array}{c}\text { Power distance index: high value: hierarchical order; low value: people equalize } \\
\text { Individualism or collectivism index: high value: individualistic; low value: } \\
\text { collectivist }\end{array}$ \\
MASC & $\begin{array}{c}\text { Masculinity or femininity index: high value: masculine; low value: feminine } \\
\text { UNA }\end{array}$ & $\begin{array}{c}\text { Uncertainty avoidance index: high value: reject uncertainty, intolerant; low value: } \\
\text { tolerates uncertainty well }\end{array}$ \\
LTO & $\begin{array}{c}\text { Index of long term or short term normative orientation: } \\
\text { high value: pragmatic, accept change, prepares with education; }\end{array}$ \\
& $\begin{array}{c}\text { low value: prefers to live by traditions, suspicious about change } \\
\text { Indulgence vs restraint index: high value: indulgence; low value: } \\
\text { represses indulgence, lives with strict constraints }\end{array}$ \\
\hline
\end{tabular}

\section{RESULTS AND DISCUSSION}

\section{Descriptive statistics and correlations}

As the descriptive analysis shows, $7.3 \%$ of the population of the EU on average considered environmental issues of major importance between 2012 and 2018. On average $12.4 \%$ of total domestic nights was spent in camping sites annually, and countries differ again a lot: the highest values were measured in Portugal in 2012, the Netherlands and UK in 2013, Denmark and Sweden in 2014 and 2017, the Netherland, Finland and Sweden in 2018, having typically coolish climates. The Hofstede cultural index values vary less, according the standard deviations relative to means (Tab. 3 and Fig. 1).

Tab. 3. Descriptive statistics of variables

\begin{tabular}{ccrrrc}
\hline & $\mathrm{N}$ & Minimum & Maximum & \multicolumn{1}{c}{ Mean } & Std. Deviation \\
\hline ENAW & 175 & 0.08 & 41.07 & 7.29 & 8.163 \\
GDP_per_cap & 175 & 5350 & 83470 & 26378 & 16855 \\
CampNPct & 175 & 0.29 & 44.78 & 12.41 & 11.287 \\
PDI & 175 & 11.00 & 104.00 & 51.88 & 21.534 \\
INDI & 175 & 27.00 & 89.00 & 58.56 & 18.242 \\
MASC & 175 & 5.00 & 110.00 & 47.00 & 25.842 \\
UNA & 175 & 23.00 & 112.00 & 70.68 & 22.842 \\
LTO & 175 & 24.43 & 82.87 & 57.00 & 16.099 \\
INDG & 175 & 12.95 & 77.68 & 43.63 & 18.795 \\
\hline
\end{tabular}




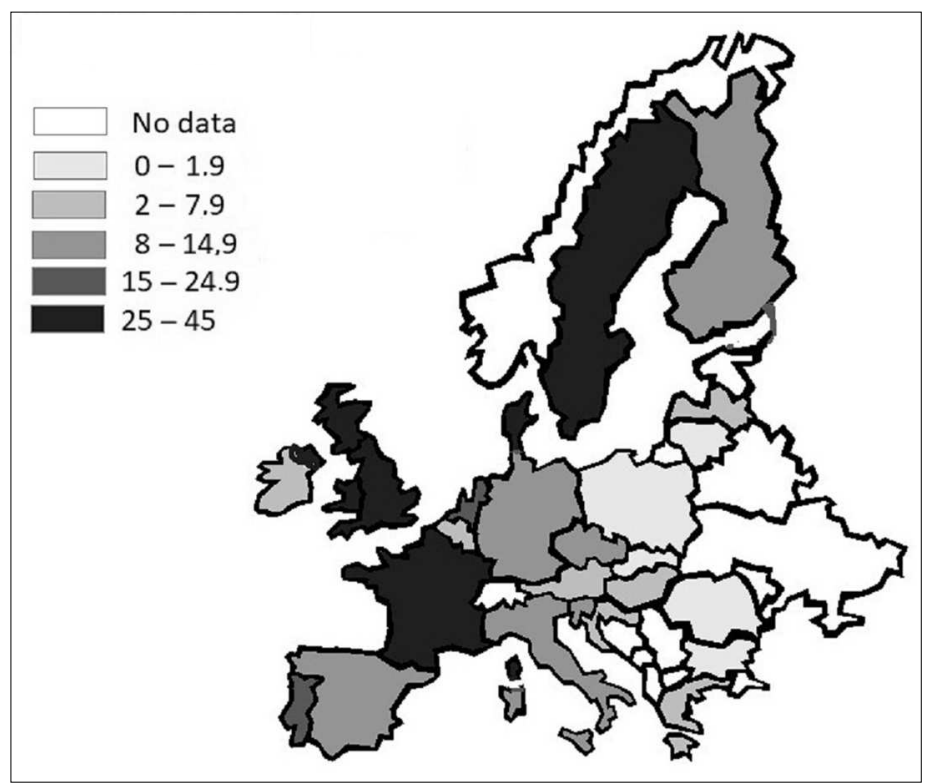

Fig. 1. Campsite nights as \% of total domestic nights in Europe, average values of $2012-2018$

Source: Authors' own construction based on Eurostat (2019a and 2019b).

As Tab. 4 shows, environmental awareness is positively correlated to camping demand, and to GDP per capita. Regarding the environmental impacts of tourism, the concept of overtourism should be mentioned. Overtourism is the result of growing tourist numbers in a given area, that leads to increasing pressures on local resources and facilities, changes in culture and loss of authenticity, deterioration of quality of life for the host community and feelings of irritation and annoyance due to the presence of tourists. This may be relevant in the case of camping, but, at the same time, camping tourism usually allows less physical contact with other people, and may therefore be a safer alternative to tourism from a sanitary-epidemiological viewpoint, too.

The proportion of domestic camping nights shows a positive correlation with GDP per capita, suggesting that with higher GDP values relatively more domestic tourist nights are spent in campsites. This may be due to the changing image of camping holidays as a cheaper form of holidays preferred by the poorer segments of the population, but the explanation may be more complex and requires further investigation. In more affluent countries camping may be just a cheaper form of a second holiday, or a usual weekend activity besides the main holiday, or it may still be the holiday form for the less affluent segments of the population, but the higher income level makes it more affordable, leading to longer stays.

The GDP level of the country is positively related to individuality and indulgence, negatively related to power distance and uncertainty avoidance. Thus, besides the two relationships known from literature two other correlations are revealed between income and culture within the EU. 
Tab. 4. Correlations between camping, environment, income and national culture

\begin{tabular}{lrrrrrrrrrr}
\hline & Year & ENAW & $\begin{array}{r}\text { Camp } \\
\text { NPct }\end{array}$ & $\begin{array}{r}\text { per_cap } \\
\text { per }\end{array}$ & PDI & INDI & MASC & UNA & LTO & INDG \\
\hline Year & 1.000 & 0.350 & -0.046 & 0.068 & 0.000 & 0.000 & 0.000 & 0.000 & 0.000 & 0.000 \\
ENAW & 0.350 & 0.052 & 0.495 & 0.518 & -0.436 & 0.394 & -0.276 & -0.518 & -0.001 & 0.572 \\
CampNPct & -0.046 & 0.495 & 1.000 & 0.628 & -0.396 & 0.360 & -0.428 & -0.442 & -0.227 & 0.614 \\
GDP_per_cap & 0.068 & 0.518 & 0.628 & 1.000 & -0.583 & 0.440 & -0.073 & -0.464 & -0.104 & 0.742 \\
PDI & 0.000 & -0.436 & -0.396 & -0.583 & 1.000 & -0.560 & 0.224 & 0.556 & 0.180 & -0.584 \\
INDI & 0.000 & 0.394 & 0.360 & 0.440 & -0.560 & 1.000 & 0.107 & -0.594 & 0.176 & 0.426 \\
MASC & 0.000 & -0.276 & -0.428 & -0.073 & 0.224 & 0.107 & 1.000 & 0.126 & 0.145 & -0.121 \\
UNA & 0.000 & -0.518 & -0.442 & -0.464 & 0.556 & -0.594 & 0.126 & 1.000 & 0.061 & -0.509 \\
LTO & 0.000 & -0.001 & -0.227 & -0.104 & 0.180 & 0.176 & 0.145 & 0.061 & 1.000 & -0.336 \\
INDG & 0.000 & 0.572 & 0.614 & 0.742 & -0.584 & 0.426 & -0.121 & -0.509 & -0.336 & 1.000 \\
\hline
\end{tabular}

The power distance index (Fig. 2), the masculinity index (Fig. 3) and the uncertainty avoidance index are negatively correlated to demand for domestic camping holidays, meaning that domestic camping is more popular where the power distance is smaller, the population possesses more feminine values, and better tolerates uncertainty. These national traits are also associated with more sensitivity towards the environment. The positive correlation with individuality (Fig. 4) and indulgence shows that a camping-oriented and environmentally sensitive population is more inclined to make individualistic decisions than collective ones, and require immediate gratification for their needs.

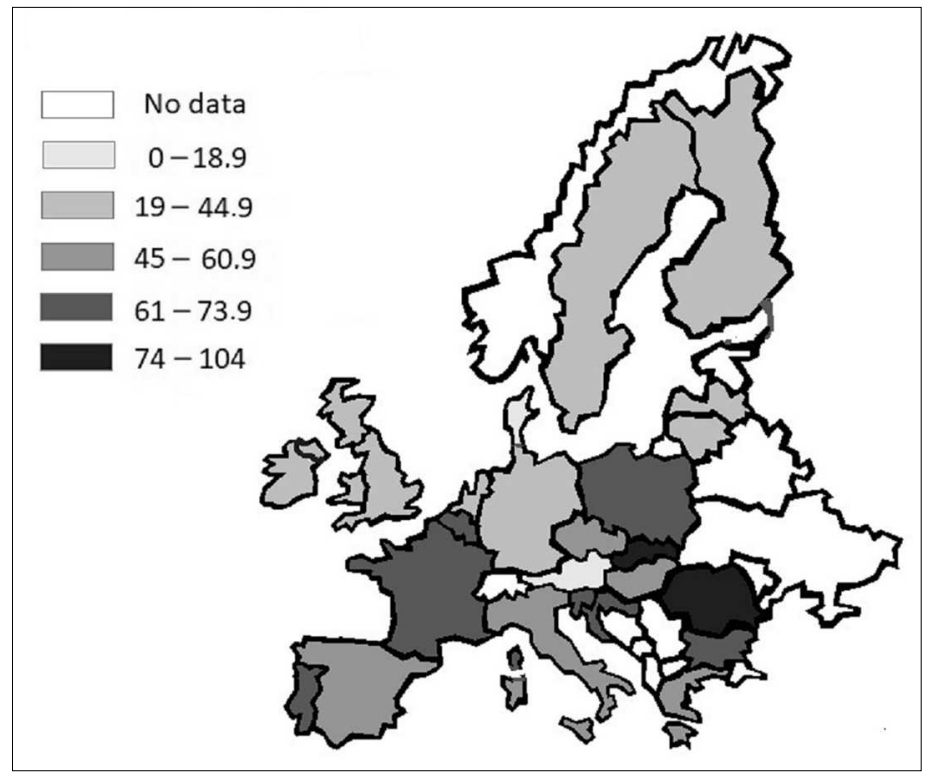

Fig. 2. Power Distance index (PDI)

(high value: hierarchical order; low value: people equalize)

Source: Authors' own construction based on Hofstede Insights (2016). 


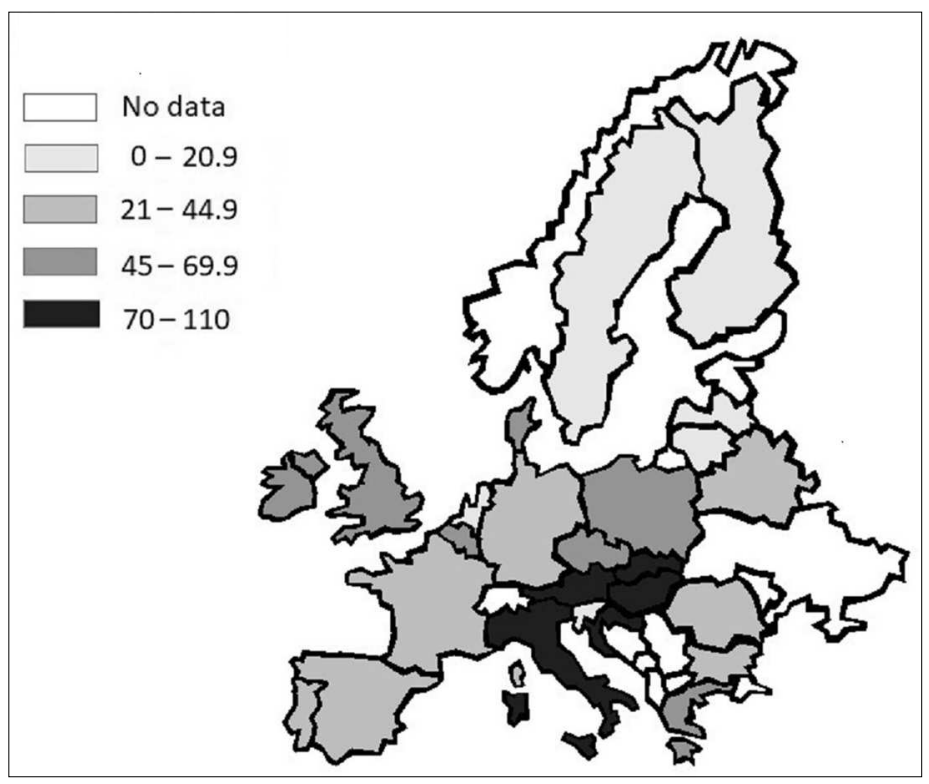

Fig. 3. Masculinity-Femininity index (MASC)

(high value: masculine; low value: feminine)

Source: Authors' own construction based on Hofstede Insights (2016).

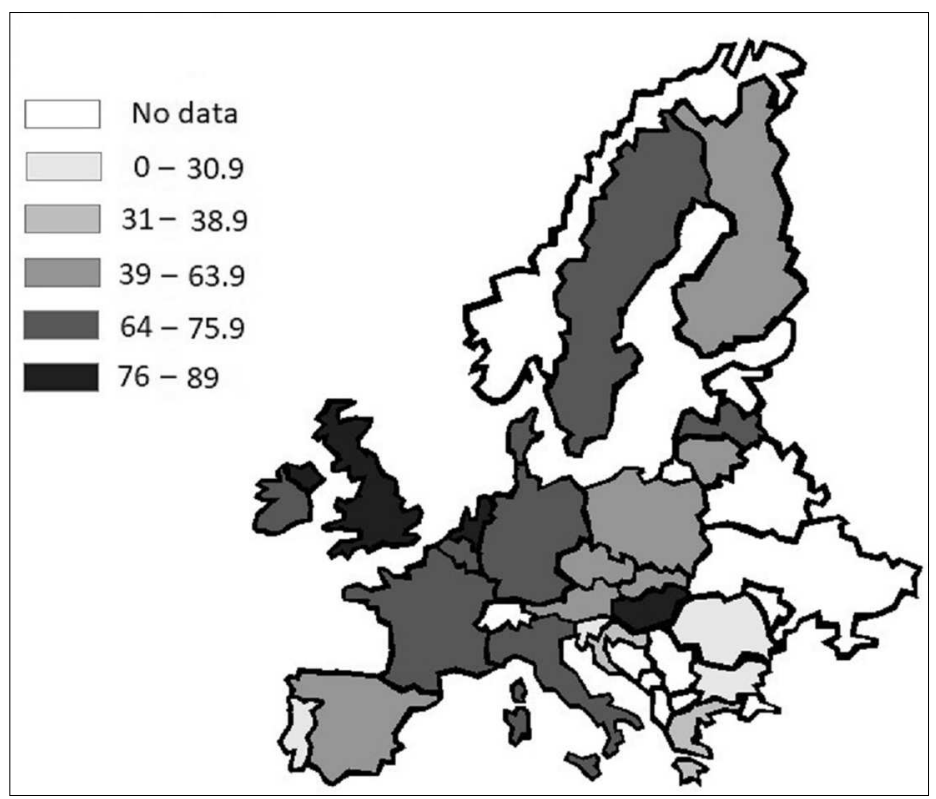

Fig. 4. Individualism-Collectivism index (INDI)

(high value: individualistic; low value: collectivist)

Source: Authors' own construction based on Hofstede insights (2016). 
Share of camping nights in domestic tourism and its relation to cultural traits

The PLM model of panel data analysis was applied for multiple regression analysis to assess the relationship of the domestic campsite nights, as the dependent variable to the independent variables of environmental awareness, income level and national cultural indicators. The model used data of 25 countries and 7 years, one dependent variable, 8 independent (and control) variables, a temporal variable (the year) and a spatial variable (the country code). As six of the variables (the Hofstede cultural dimensions) did not change with time, a fixed effect panel model was not applicable (as these cultural variables could not be distinguished from the fixed individual error term). Therefore the random effects model was applied for our analysis. Tab. 5 presents the results.

As Tab. 5 shows the dependent variable is significantly influenced by Hofstede cultural values. Larger power distance, larger levels of individualistic attitude, larger level of indulgence and higher GDP per capita were positively related to the percent of campsite nights by domestic tourists. Interestingly, the level of environmental awareness seems to be neutral, while higher levels of masculinity and of long-term orientation showed a significant negative relationship with the proportion of domestic camping nights. The fit of the model is quite reasonable, the model explains $63 \%$ of the variance in the proportion of camping nights in domestic tourism.

The impact of the year is negative, meaning that the share of camping nights decreases with time. The same model was tested with the year variable as a dummy, but in that case none of the years showed any significant relationship with the dependent variable.

Tab. 5. Coefficients and model fit, Dependent: CampNPct (PLM, random effects model)

\begin{tabular}{cccccc}
\hline & Coefficient (Est.) & Std. Error & $\mathrm{z}$-value & $\mathrm{p}(>|\mathrm{z}|)$ & signif. \\
\hline (Intercept) & 1263.1 & $5.9747 \mathrm{e}+02$ & 2.1141 & 0.034505 & $*$ \\
Year & -0.62773 & $2.9651 \mathrm{e}-01$ & -2.1171 & 0.034255 & $*$ \\
ENAW & 0.13310 & $1.0008 \mathrm{e}-01$ & 1.3299 & 0.183537 & \\
GDP_per_cap & 0.0003137 & $4.9729 \mathrm{e}-05$ & 6.3088 & $2.813 \mathrm{e}-10$ & $* * *$ \\
PDI & 0.16002 & $3.6421 \mathrm{e}-02$ & 4.3936 & $1.115 \mathrm{e}-05$ & $* * *$ \\
INDI & 0.16919 & $4.2877 \mathrm{e}-02$ & 3.9460 & $7.945 \mathrm{e}-05$ & $* * *$ \\
MASC & -0.18222 & $2.2977 \mathrm{e}-02$ & -7.9305 & $2.183 \mathrm{e}-15$ & $* * *$ \\
UNC & -0.022927 & $3.2367 \mathrm{e}-02$ & -0.7083 & 0.478728 & \\
LTO & -0.11964 & $3.9533 \mathrm{e}-02$ & -3.0264 & 0.002475 & $* *$ \\
INDG & 0.085105 & $5.1668 \mathrm{e}-02$ & 1.6472 & 0.099526 & + \\
\hline Goodness of fit: & $R^{2}=0.64957$ & Adj. $R^{2}=0.63045$ & $\mathrm{p}$-value $<$ & $2.22 \mathrm{e}-16$ \\
\hline
\end{tabular}

Signif. codes: ‘***’: $0.001 ;$ ‘**’: 0.01 ; ‘*’: $0.05 ;$; +’: 0.1 .

As the model showed, with higher per capita income levels the share of domestic nights spent in camping grounds is also higher. As it was mentioned earlier, this may be due to a higher preference for nature-focused recreation in more affluent 
countries, enhanced by the increased attention paid to the conditions of the natural environment, or to the affordability of camping tourism as the main holiday for the poor, or a second holiday or weekend recreation for the more affluent segments of the society.

The positive coefficients of the PDI and INDI variables show, that the share of camping nights is higher in countries where the population shows higher power distance, or more individualistic orientation.

The results are illustrated by the examples of a few countries. In France, for example, with one of the highest share of domestic camping nights $(27.1 \%$, as an annual average in 2012-2018) a very high PDI (68) and INDI (71) show an individualistic society with respect for hierarchy and slightly more feminine values $(\mathrm{MASC}=43)$ than the European average. The very high percentages of camping nights within domestic tourism in Sweden (28.2\%) and Denmark (42.2\%) are accompanied with extremely individualistic and feminine values (Sweden: INDI=71, MASC $=5$; Denmark: INDI $=74, \mathrm{MASC}=16$ ), although their PDI values are low. Slovenia also has an above-average share of domestic camping nights $(14.3 \%)$, which is associated with high power distance $(\mathrm{PDI}=71)$, and rather feminine social values (MASC $=19$ ). At the other end of the scale, low domestic camping night shares are seen in Hungary (4.5\%), Lithuania (1.1\%) and Slovakia (1.2\%) with below-average power distance values in Hungary $(\mathrm{PDI}=45)$ and Lithuania $(\mathrm{PDI}=42)$, while Hungary is very masculine (MASC $=88)$, and Lithuania is long-term-oriented $(\mathrm{LTO}=88)$. Slovakia, although being high on power distance $(\mathrm{PDI}=104)$, is both a very masculine $(\mathrm{MASC}=105)$ and a rather long-term oriented society $(\mathrm{LTO}=77)$. The low level of camping nights occur not only in poorer countries of the EU, but in countries of higher GDP, e.g. in Austria with its 3.8\% of camping nights and Belgium with $6.8 \%$ camping nights, due to their rather masculine, or long-term oriented societal values (Austria: $\mathrm{PDI}=11, \mathrm{MASC}=79$; Belgium: $\mathrm{MASC}=54$, $\mathrm{LTO}=82$ ). As the example of the Scandinavian countries show, domestic camping is not determined by climatic features, but it is definitely influenced by living standards and cultural traditions.

Our findings show, that while large power distance establishes a definite hierarchical organisation in society, higher preference for individual freedom and free choice is still reflected in the preferences for camping holidays. This is similar to the results by Gursoy and Chen (2012) for Taiwan. The positive significance of individualism is similar to Jackson's findings (Jackson 2001), who, in analysing the destination choices of tourists from the Pacific Rim to the same region found that nations scoring high on individualism chose culturally similar destinations, while those of more collectivist features were more likely to visit dissimilar destinations. This suggests that in indiviualistic countries domestic tourism may be higher, while in collectivist countries people are more inclined to go to other destinations.

According to our results, in countries where people are more long-termoriented, the preference for camping holidays is lower, possibly because people favour tradition, and are less open towards the everchanging natural environment. More masculine societies tend to show less preference for camping holidays, probably because the sensitivity and care for the environment is more associated with feminine values, as the negative correlation between ENAW and MASC suggests in Tab. 4. 
In a recent research about Nordic destinations (Kristjánsdóttir 2019) the number of inbound tourists was analysed against Hofstede's dimensions of national culture, and several other control variables. The results showed that masculinity and longterm vs. short-term orientation had significant negative relationships with tourist arrivals, while individuality and uncertainty avoidance were positively related to it, and power distance showed a small negative impact. Research on satisfaction of visitors from UK, Korea, Australia, Germany, China and France to Samui Island (Thailand) found a significant negative impact of masculinity on tourist satisfaction (Buafai and Khunon 2016), which suggests a similar relationship with actual travels and stays.

Our results reveal, that the higher power distance is associated with more campsite nights, which is in contrast to Li et al. (2007) about California, where campers were characterised by less hierarchical beliefs. This may be due to the cultural differences between Europe and California, or the time elapsed since 2007. Indeed, in the sample by Li et al. (2007), most respondents were more hierarchically oriented, more attached to feminine values and more afraid of uncertainties, than the European average.

\section{CONCLUSIONS}

The model presented in the analysis underline that the popularity of camping tourism is related to the national cultural traits, but not to the environmental sensitivity of the population, i.e., to the percentage of people who put the environmental issues among the most important concerns of their countries.

Our findings are partly in line with the findings in earlier studies about camping tourism. According to the literature camping tourists are more conscious about environmental issues and campgrounds are more environmentally sustainable forms of tourist accommodation than hotels and other type of accommodations. However, our results show, that the environmental sensitivity of the population is unrelated to the share of domestic tourist nights spent in campsites. People in more affluent countries tend to spend relatively more of their holiday time in campsites, and they can also afford well-equipped, comfortable campsites, as in 'glamping' tourism. People in more hierarchical cultures are more inclined to spend their leisure time in uncontrolled environments, evoking the feelings of freedom and escape from civilisation, leading to higher preference for camping holidays, and this is also true in countries of more individualistic cultures. Countries with more nights spent in domestic camping are less long-term oriented, which indicates that campers are probably more oriented towards traditional values and are suspicious about change. This may be an explanation for low environmental concern, too.

Masculinity showed a negative relationship with preference for camping holidays, although camping lifestyles in the wildlife are often stereotyped as a rather macho way of living. However, the changing attitudes towards nature and the environment reveal the more emotional aspects of camping holidays. The uncertainty avoidance factor is neutral, but this variable was rather strongly correlated with individualistic orientation (negatively) and power distance (positively), therefore its characteristics are probably captured by those variables.

Limitations of the present research include the geographic limits of Europe, as cultural traits and attitudes toward nature may differ considerably in other conti- 
nents. It would also be worthwhile to analyse European country groups separately - either by their climatic and environmental features, or by their cultural traits, to see whether specific patterns of domestic camper behaviour can be identified. Learning about the impacts of behavioural standards and cultural values of people can help service providers to develop services that offer quality experience together with sustainability for campers and nature-based tourists. The present assessment could be applied in country-specific marketing actions towards prospective campers, focusing on the campsite offerings from a cultural viewpoint. A similar analysis, using the measures of national cultural dimensions of other models could be carried out and compared to the present findings. The World Values Survey regularly updates the measures of cultural dimesions, although for fewer countries, and thus it would be worthwile to do a similar analysis with these values to evaluate the impacts of changing cultural patterns of countries, too.

The authors acknowledge the financial support of Széchenyi 2020 under the EFOP-3.6.1-16-2016-00015 project.

\section{REFERENCES}

BACSI, Z. (2017). Tourism and diversity. Deturope, 9(2), 25-57.

BLICHFELDT, B. S., MIKKELSEN, M. V. (2014). Camping, tourism. In Jafari J., Xiao H., eds. Encyclopedia of Tourism. Cham, Heidelberg, New York, Dordrecht, London (Springer). DOI: https://doi.org/10.1007/978-3-319-01669-6_468-1.

BROCHADO, A., PEREIRA, C. (2017). Comfortable experiences in nature accommodation: Perceived service quality in Glamping. Journal of Outdoor Recreation and Tourism, 17, 77-83. DOI: http://dx.doi.org/10.1016/j.jort.2017.01.005.

BROOKER, E., JOPPE, M. (2013). Trends in camping and outdoor hospitality - an international review. Journal of Outdoor Recreation and Tourism, 3-4, DOI: http:// dx.doi.org/10.1016/j.jort.2013.04.005.

BROOKER, E., JOPPE, M. (2014). A critical review of camping research and direction for future studies. Journal of Vacation Marketing, 20, 335-351.

BUAFAI, T., KHUNON, S. (2016). Relationship between Hofstede's cultural dimensions and tourism product satisfaction. International Journal of Economics and Management Engineering, 10, 2984-2988. DOI: https://doi.org/10.5281/zenodo.1126533.

CROISSANT, Y., MILLO, G. (2008). Panel data econometrics in R: The plm Package. Journal of Statistical Software, 27(2), 1-43. DOI: http://www.jstatsoft.org/v27/i02/.

EAGLESTON, H., MARION, J. L. (2017). Sustainable campsite management in protected areas: A study of long-term ecological changes on campsites in the boundary waters canoe area wilderness, Minnesota, USA. Journal for Nature Conservation, 37, 73-82. DOI: http://dx.doi.org/10.1016/j.jnc.2017.03.004.

EC (2012 - 2019). Standard Eurobarometer surveys No.77-N.92. EC Public Opinion, [Online]. Available: https://ec.europa.eu/commfrontoffice/publicopinion/index.cfm/ Survey/index\# $\mathrm{p}=1 \&$ instruments=STANDARD [accessed 21 December 2019].

EC (2013). Best environmental management practice in the tourism sector. European Commission, JRC Scientific and Policy Reports, [Online]. Available: http:// publications.jrc.ec.europa.eu/repository/bitstream/JRC82602/tourismbemp.pdf. [accessed 21 December 2019].

ESS (2008). ESS Round 4: European Social Survey Round 4 Data (2008). Data File Edition 4.0. Norwegian Social Science Data Services, Norway - Data Archive and Distributor of ESS Data. ESS, Norway.

EUROSTAT (2019a). Tourism trips of Europeans - Statistics explained. tourism statisticscharacteristics of tourism trips, [Online]. Available: https://ec.europa.eu/eurostat/ 
statistics-explained/index.php/Tourism statistics - characteristics of tourism trips. [accessed 03 February 2020].

EUROSTAT (2019b). Number of nights spent by mode of accommodation [tour_dem tnac], [Online]. Available: http://appsso.eurostat.ec.europa.eu/nui/show.do. [accessed 03 February 2020].

EUROSTAT (2019c). GDP per capita data series, [Online]. Available: https://ec.europa.eu/ eurostat $/$ tgm $/$ table.do?tab $=$ table\&plugin $=1 \&$ language $=$ en\&pcode $=$ sdg $08 \quad 10$ [accessed 03 February 2020].

EVS (2010). European values study 2008, 4th Wave, Integrated Dataset. GESIS Data Archive, Cologne, ZA4800 Data File Version 2.0.0, [Online]. Available: http:// dx.doi.org/10.4232/1.10188 [accessed 30 November 2010].

FAN, D. X. F., LIU, A., QIU, R. T. (2017). The impact of the culture distance on tourism demand - An econometric method from a global perspective. In Advances in Tourism Marketing Conferences 2017, 6-9 September 2017, Casablanca, Morocco, pp. 1-5.

GOULD, R. K. , KRYMKOWSKI, D. H., ARDOIN, N. M. (2018). The importance of culture in predicting environmental behaviour in middle school students on Hawai' $i$ Island. PLoS ONE 13(11), e0207087. DOI: https://doi.org/10.1371/journal.pone.0207087.

GURSOY, D., CHEN, B. T. (2012). Factors influencing camping behaviour: The case of Taiwan, Journal of Hospitality Marketing \& Management, 21, 659-678. DOI: http://dx.doi.org/10.1080/19368623.2012.627239.

HALKOS, G. E., TZEREMES, N. G. (2013). National culture and eco-efficiency: An application of conditional partial nonparametric frontiers. Environmental Economics and Policy Studies, 15, 423-441, DOI: https//doi.org/10.1007/s10018-013-0066-6.

HOFSTEDE INSIGHTS (2016). [Online]. Available: https://geerthofstede.com/wp-content/ uploads/2016/08/6-dimensions-for-website-2015-08-16.xls [accessed 03 February 2020].

HOFSTEDE, G. (1980). Culture's consequences: International differences in work related values. Beverly Hills (Sage).

HOFSTEDE, G., HOFSTEDE, G. J., MINKOV, M. (2010). Cultures and organizations: Software of the mind. New York (McGraw-Hill).

JACKSON, M. (2001). Cultural influences on tourist destination choices of 21 Pacific Rim Nations. Paper presented at the CAUTHIE national research conference, Camberra, Australia, 7 - 10 February 2001, Proceedings, pp. 166-176.

KAASA, A., VADI, M., VARBLANE, U. (2016). A new dataset of cultural distances for European countries and regions. Research in International Business and Finance, 37, 231-241.

KLAMÁR, R., GAVALOVÁ, A. (2018). Regional application of the Gross National Happiness Index in the context of the quality of life in Slovakia. Geografický časopis, 70, 315-333. DOI: https://doi.org/10.31577/geogrcas.2018.70.4.17.

KRISTJÁNSDÓTTIR, H. (2019). Tourism in a remote Nordic region: Vat, internet, oil, English, distance, Hofstede, and Christianity. Cogent Social Sciences, 5(1), 1709346. DOI: https://doi.org/10.1080/23311886.2019.1709346.

LI, C.-L. (2016). Why do people travel to nature based tourism destinations? Travel and Tourism Research Association: Advancing Tourism Research Globally, 48, [Online]. Available: https://scholarworks.umass.edu/tra/2009/Presented Papers/48 [accessed 03 February 2020].

LI, C.-L., ZINN, H. C., CHICK, G. E., ABSHER, J. D., GRAEFE, A. R., HSU, Y-C. (2007). Segmentation of culturally diverse visitors' values in forest recreation management. Forest, Snow and Landscape Research, 81, 19-29.

LITVIN, S. W., CROTTS, J. C., HEFNER, F. L. (2004). Cross-cultural tourist behaviour: A replication and extension involving Hofstede's Uncertainty Avoidance dimension. International Journal of Tourism Research, 6, 29-37. DOI: https://doi.org/10.1002/ jtr.468. 
MANRAI, L. A., MANRAI, A. K. (2011). Hofstede's cultural dimensions and tourist behaviours: A review and conceptual framework. Journal of Economics, Finance and Administrative Science, 16(31), 23-48.

MATLOVIČOVÁ, K., TIRPÁKOVÁ, E., MOCÁK, P. (2019). City brand image: Semiotic perspective. A case study of Prague. Folia Geographica, 61, 120-142.

MIKULIC, J., PREBEL, D., SERIC, M., KRESIC, D. (2017). Campsite choice and the camping tourism experience: Investigating decisive campsite attributes using relevancedeterminance analysis. Tourism Management, 59, 226-233. DOI: https://doi.org/ 10.1016/j.tourman.2016.07.020.

MINCA, C. (2013). The cultural geographies of landscape. Hungarian Geographical Bulletin, 62(2). 47-62.

MINKOV, M. (2007). What makes us different and similar: A new interpretation of the World Values Survey and other cross-cultural data. Sofia (Klasika i Stil).

MURGAŠ, F. (2019). Can Easterlin's paradox be applied to the development of satisfaction with life or does the explanation lie in cultural geographical characteristics? Geografický časopis, 71, 3-14. DOI: https://doi.org/10.31577/geogrcas.2019.71.1.01.

NESZMÉLYI, G. I., LAMPERTNÉ AKÓCSI, I., BRUDER, E. (2016). The evolution of the regional disparities in the Visegrad Group in the years 1995 - 2014. Geograficky časopis, 68, 283-299.

PEARCE, D. (1995). Tourism today. A geographical analysis. Essex (Longman Scientific \& Technical).

PEETERS, P., LANDRÉ, M.(2012). The emerging global tourism geography - An environmental sustainability perspective. Sustainability, 4, 42-71. DOI: https://doi.org/ $10.3390 / \mathrm{su} 4010042$.

PELUSO, A. M., BARBAROSSA, V., CHIEFFI, V., GUIDO G. (2019). Effects of slow tourism experience dimensions on visitors' intention: an empirical study on camping. In Global issues and challenges for accessibility and sustainable tourism. Book of abstracts of the global management perspectives, 4th International Annual Conference, Lecce, 1-2 March 2019, p. 19.

PIZAM, A., SUSSMANN, S. (1995). Does nationality affect tourist behaviour? Annals of Tourism Research, 22, 901-917. DOI: https://doi.org/10.1016/0160-7383(95)00023-5.

PIZAM, A., TELISMAN-KOSUTE, N. (1989). Tourism as a factor of change: Results and analysis. In Bystrzanowski, J., ed. Tourism as a factor of change: A socio-cultural study I. Vienna (European Coordination), pp. 249-156.

R CORE TEAM (2013). $R$ : A language and environment for statistical computing. Vienna ( $\mathrm{R}$ Foundation for Statistical Computing ). [Online]. Available: http://www.Rproject.org/ [accessed 01 October 2020].

REISINGER, Y., CROTTS, J. C. (2010). Applying Hofstede's national culture measures in tourism research: Illuminating issues of divergence and convergence. Journal of Travel Research, 49, 153-164. DOI: https://doi.org/10.1177/0047287509336473.

RYALLS, A., PETRI, R. L.(2013). Camping. In Encyclopedia Britannica, [Online]. Available: https://www.britannica.com/topic/camping. [accessed 26 February 2021].

SAARINEN, J. (2014). Tourism geographies: Connections with human geography and emerging responsible geographies. Geographia Polonica, 87, 343-352. DOI: http:// dx.doi.org/10.7163/GPol.2014.23.

SANDELL, K., ÖHMAN, J. (2010). Educational potentials of encounters with nature: Reflections from a Swedish outdoor perspective. Environmental Education Research, 16, 113-132. DOI: https://doi.org/10.1080/13504620903504065.

SHAKER, R. R. (2015). The spatial distribution of development on Europe and its underlying sustainability correlations. Applied Geography, 63, 304-314. DOI: https://doi.org/ 10.1016/j.apgeog.2015.07.009.

STEERS, R. M., SANCHEZ-RUNDE, C. J., NARDON, L. (2010). Management across cultures - challenges and strategies. Cambridge, New York, Tokyo (Cambridge University Press). 
WARD, C., HARDY, D. (1986). Goodnight campers!: The history of the British holiday camp (Studies in history, planning and the environment). Oxford (Alexandrine Press).

Zsuzsanna B a cs $i$, Angéla $S$ z a n a t $i$

\section{VPLYV NÁRODNEJ KULTÚRY A ENVIRONMENTÁLNEHO POVEDOMIA NA DOPYT PO DOMÁCOM KEMPINGOVOM CESTOVNOM RUCHU - POROVNANIE EURÓPSKYCH KRAJÍN}

Prírodné podmienky sú hlavnými zdrojom cestovného ruchu a prírodný turizmus je jednou z jeho foriem, ktorá je prít’ažlivá pre čoraz viac turistov. Kempingový cestovný ruch je dôležitou súčastou turizmu orientovaného na prírodu a zohráva významnú úlohu v domácom cestovnom ruchu, hoci je jeho význam v jednotlivých krajinách do značnej miery odlišný. Rozhodnutie turistov vybrat' si dovolenku v kempingu závisí od ich preferencií a hodnôt. V príspevku poukazujeme na to, že tieto hodnoty a preferencie korešpondujú s charakteristikami národnej kultúry. Na zachytenie tohto vzt’ahu sme využili Hofstedeho teóriu šiestich národných kultúrnych dimenzií. Analýza je založená na údajoch o 25 krajinách EÚ z obdobia rokov 2012 - 2018 z databáz Eurostatu a Eurobarometra. Vo viacnásobnom regresnom modeli sú závislou premennou prenocovania $\mathrm{v}$ súkromných kempingoch vyjadrené ako ich podiel z celkového počtu prenocovaní, šest' premenných kultúrnej dimenzie podl'a Hofstedeho predstavuje nezávislé premenné, zatial' čo rok, úroveň príjmu a environmentálne povedomie obyvatel'stva sú kontrolnými premennými.

Výsledky poukazujú na to, že výber kempingu domácimi turistami koreluje s väčšinou Hofstedeho kultúrnych dimenzií a s úrovňou príjmu a naopak, nie je v korelácii s environmentálnym povedomím obyvatel'stva. Naše výsledky sú čiastočne v súlade $\mathrm{s}$ výsledkami z predchádzajúcich štúdií o kempingovom turizme. Podla literatúry si kempujúci turisti viac uvedomujú problémy životného prostredia a kempingy predstavujú environmentálne udržatel'nejšie formy ubytovania turistov v porovnaní s hotelmi či inými možnost’ami ubytovania. Avšak naše výsledky ukazujú, že citlivost' populácie na environmentálne otázky nesúvisí s podielom prenocovaní domácich turistov v kempingoch. L’udia v bohatších krajinách majú tendenciu strávit' relatívne viac svojho dovolenkového času v kempingoch. L'udia vo viac hierarchizovaných kultúrach skôr inklinujú $\mathrm{k}$ tomu, aby trávili svoj vol'ný čas v prostredí, ktoré nie je kontrolované, ktoré viac evokuje pocity slobody a únik od civilizácie. To vedie $\mathrm{k}$ zvýšeným preferenciám dovoleniek $\mathrm{v}$ kempingu, čo platí aj v krajinách, ktorých kultúra je viac individualistická.

Krajiny s väčším podielom domácich prenocovaní v kempingoch sú menej orientované na dlhodobé pobyty, čo naznačuje, že títo turisti sa pravdepodobne viac orientujú na tradičné hodnoty a sú nedôverčiví voči zmenám. Medzi mužmi bol zistený negatívny vzt’ah k preferencii kempingových dovoleniek, hoci životný štýl spojený s kempovaním vo vol'nej prírode je často považovaný za stereotyp spôsobu života typu „macho”. Avšak meniace sa postoje voči prírode a životnému prostrediu odhal'ujú aj emocionálnejšie aspekty dovoleniek v kempingoch. Miera vyhýbania sa neistote je neutrálna, avšak táto premenná pomerne silno korelovala s orientáciou na individualizmus a mierou akceptácie moci, preto ich charakteristiky tieto premenné pravdepodobne zachytávajú.

K obmedzeniam nami realizovaného výskumu patria geografické hranice Európy, pretože kultúrne osobitosti a postoje k prírode sa môžu na iných kontinentoch značne líśit'. Bolo by potrebné analyzovat jednotlivé skupiny európskych krajín - bud' na základe ich klimatických a environmentálnych čŕt, alebo kultúrnych osobitostí.

Štúdium vplyvu štandardov správania a kultúrnych hodnôt l'udí môže pomôct' poskytovatel'om služieb rozvíjat' služby, ktoré ponúkajú kvalitný zážitok a udržatel'nost' turistom v kempingoch a prírodne založeným turistom. Toto hodnotenie sa dá aplikovat' na marketin- 
gové aktivity špecifické pre jednotlivé krajiny zamerané na potenciálnych návštevníkov kempingov, ktoré sú orientované na ponuku kempingov z kultúrneho hl'adiska. Analýzu možno vykonat' aj opakovane v iných modeloch s využitím charakteristík národnej kultúry.

(c) (i) Article first received: December 2020

Article accepted: March 2021 